\title{
A new species of Tiaracrinus from the latest Emsian of Morocco and its phylogeny
}

Christian Klug, Kenneth De Baets, Carole June Naglik, and Johnny Waters

Acta Palaeontologica Polonica 59 (1), 2014: 135-145 doi: http://dx.doi.org/10.4202/app.2011.0188

We describe a new species of the unusual crinoid Tiaracrinus, $T$. jeanlemenni sp. nov. from the latest Emsian of the famous mudmound locality Hamar Laghdad, Morocco. It differs from the previously known species in the higher number of ribs and the vaulted rib-fields, which is corroborated by the comparison of simple quantitative characters and ratios as well as by the results of a cluster analysis and a Principal Component Analysis. Based on the new material and the published specimens, we discuss the phylogeny of the genus and suggest that $T$. oehlerti and $T$. moravicus represent the ancestral forms of this small clade.

Key words: Crinoidea, mudmounds, phylogeny, morphometry, symmetry, Devonian, Morocco.

Christian Klug [chklug@pim.uzh.ch] and Carole J. Naglik [carole.naglik@pim.uzh.ch ], Paläontologisches Institut und Museum, Universität Zürich, Karl Schmid-Strasse 4, CH-8006 Zürich, Switzerland; Kenneth De Baets [kenneth.debaets@ @au.de ], GeoZentrum Nordbayern, Fachgruppe PaläoUmwelt, Universität Erlangen, Loewenichstr. 28, D-91054 Erlangen, Germany; Johnny Waters [watersja@ appstate.edu], Department of Geology, Appalachian State University, ASU Box 32067, Boone, NC 28608-2067, USA.

This is an open-access article distributed under the terms of the Creative Commons Attribution License (for details please see creativecommons.org), which permits unrestricted use, distribution, and reproduction in any medium, provided the original author and source are credited. 
